\title{
The Challenges in the Formation of State Asset Management Agency (LMAN) based on Mintzberg's Theory of Organizational Structure
}

\author{
Lina Miftahul Jannah \\ Faculty of Administrative Science \\ Universitas Indonesia \\ Depok, Indonesia \\ miftahul@ui.ac.id
}

\author{
Akhmad Yuzkhar Lutfansa \\ Faculty of Administrative Science \\ Universitas Indonesia \\ Depok, Indonesia \\ ayuzkhar@gmail.com
}

\begin{abstract}
Indonesia has a considerable amount of asset from Sabang to Merauke. Since 2015, the responsibility towards these assets belongs to the State Asset Management Agency (Indonesian: Lembaga Manajemen Aset Negara, shortened LMAN). LMAN is an agency which structured with two divisions and one functional position, while LMAN has quite a lot of challenges. Based on the problem, this research has a goal in illustrating the challenges that are currently faced by the organizational structure of LMAN. This research used a qualitative method and comprehensive interview for the data collection and also literature review. The result shows that with the current structural organization of LMAN, there are three main challenges, which are a great responsibility, the over-simple structure and the status of non-echelon. Based on these challenges, it is concluded that the ideal configuration of LMAN organizational structure is the Divisionalized Form.
\end{abstract}

Keywords-State Asset Management Agency (LMAN), Organizational Structure, Asset Management, The Divisionalized Form

\section{INTRODUCTION}

One of the problems in the management of State-owned Property (BMN) is that some assets that do not go on record. According to National Procurement Agency (LKPP) in 2015, the amount of State's asset is 5.163,32 trillion rupiah. This abundant amount is still yet to illustrate the whole assets that belong to the country. There are still problems related to the records of these assets. State-owned Property, according to the Law Number 1 Year 2004 on State's Treasury, is every property that is bought or obtained with State's Budget (APBN) or coming from other legal sources. Other legal sources come from grants and confiscated goods.

The problems happened due to the lack of supervision towards the State's property. The one in charge to supervise the State's Property is the House of Representatives (DPR) and the Regional Legislative Councils (DPRD). However, the supervision from both parties is very limited. It can be seen from the Law about National Treasury Article 45 clause (2), article 46 and article 47 . The authority of DPR/DPRD, in this case, is to give their approval or disapproval depending on the result of the research. According to the Law of National Treasury, the DPR and DPRD have limited authority because, first, only towards the process of changing the authority from the State's goods or the regional's that are not needed anymore in the process of ministry, agency and regional government and their working units. Second, the authority is limited only to land and buildings (inanimate objects) according to the article 46 clause (1) alphabet a. Third, the authority to supervise the process of changing the authority from inanimate goods like land and building are being specified more in the article 46 clause (1) alphabet $b$.

The lack of supervision towards the management of asset in this country has encouraged a joint initiative between The Ministry of Finance and Directorate General of State Assets (DJKN) to create an agency that is called the State Asset Management Agency (LMAN). According to the regulation of Finance Ministry Number 219 Year 2015 about Organization and Working Procedure of the State Asset Management Agency, LMAN was created to support the optimization of the State's Property management for the economic and social improvement as well as finding the potential of return on assets and Non Tax Revenues coming from the State's Property. LMAN is a non-echelon organization unit in the scope of Finance Ministry that is responsible to and is under the Finance Ministry through the DJKN. LMAN has the duty of serving, utilizing, authoritychanging, consulting, assessing, implementing construction, managing, securing, planning needs, and developing in the scope of State's asset and also legal handling, reporting and evaluating the management of the State's asset.

In 2016, the Ministry of Finance proposed a suggestion to the president that says the process of land supply should be carried out by LMAN to perform the land banking function with the purpose of the integrated land supply process is owned by the government. The land bank function has a high complexity and tough workload, as well as a high financial dimension. One unit of a division would not be sufficient for the work. While at the same time, the division must carry out the utility function and also asset authority-change with a high complexity and workload. 
LMAN is configured with two divisions and one functional position. Both divisions have different characteristics, one acts as a support and the other works as the executor of all tasks and the function of LMAN.

\section{LITERATURE REVIEW}

One of the theories on organizational structure is Mintzberg's Theory (1980) that came up with five basic parts of an organization. The dominance of one part will affect the configuration result of a particular organizational structure. The five basic parts are: (1) the part of an organization that directly deals with the activities necessary to deliver outputs (The Operating Core); (2) the top management that is responsible for the organization as a whole (The Strategic Apex); (3) the managers that provide link between the operational part with the top management (The Middle Line); (4) the analyzers that are accountable to the formation of organization's activities (The Techno structure); (5) the working staff in each unit which provides support for daily organizational activities (The Supporting Staff).

If the operating core holds an important role, the decisions in the organization would be obtained in a decentralized manner. This condition would result in professional bureaucracy structural configuration. If the strategic apex holds a dominant role, control would be done centrally, so that the organization would have the form of simple structure. If the leading role is carried out by the middle line, there would be found groups that are a part of divisional structure configuration. When an organization is dominated by the technostructure, control would be performed through standardization, so that the structural configuration that is produced is machine bureaucracy. In a situation where the one that holds the major role is the supporting staff, control is performed through manual adjustment and through adhocracy structural configuration.

Simple structure configuration uses mutual adjustment coordination mechanism and direct supervision. Mutual Adjustment is the simplest form of coordination that occurs through informal communication by two or more people talking to each other directly. While direct supervision are more formal coordination mechanism in terms of control. In this case someone is responsible for the work of others.

The development of the organization with increasing department and hierarchy will cause the increasing size of the organization, while adding vertical and horizontal differentiation. This development is usually followed by the standardization and formalization of behavior that is typical of machine bureaucracy. This organizational configuration has a key coordination mechanism in the form of direct supervision and standardization of work processes, resulting in various work procedures to be followed and responsible for a job. Organizations with high specialization and have unskilled workers will greatly benefit from coordination in the form of standardization of work process.

Professional Bureaucracy configuration occurs the formalization of behavior. The main coordinating mechanism used is the standardization of units. Thus, the work within this organization is solved based on the expertise of the person in charge. Expertise is the hallmark of employees in this organization.

The Divisionalized Form configuration has a decentralized structure that includes aspects of departmentalization by project or product design. This type of organization is a collection of autonomous companies with the same owner. The main coordinating mechanism is the standardization of output, so the performance of managers and organizations is judged on the basis of their output.

Ad hoc organizations or committees use a variety of temporary ad hoc and liaison devices to encourage mutual adjustment coordination mechanisms among their members. Such an organizational structure is a flexible structure to respond from rapid and complex environmental changes. Information technology will be instrumental in supporting work teams within such structures.

Table1 - Elements of the Five Structural Configurations

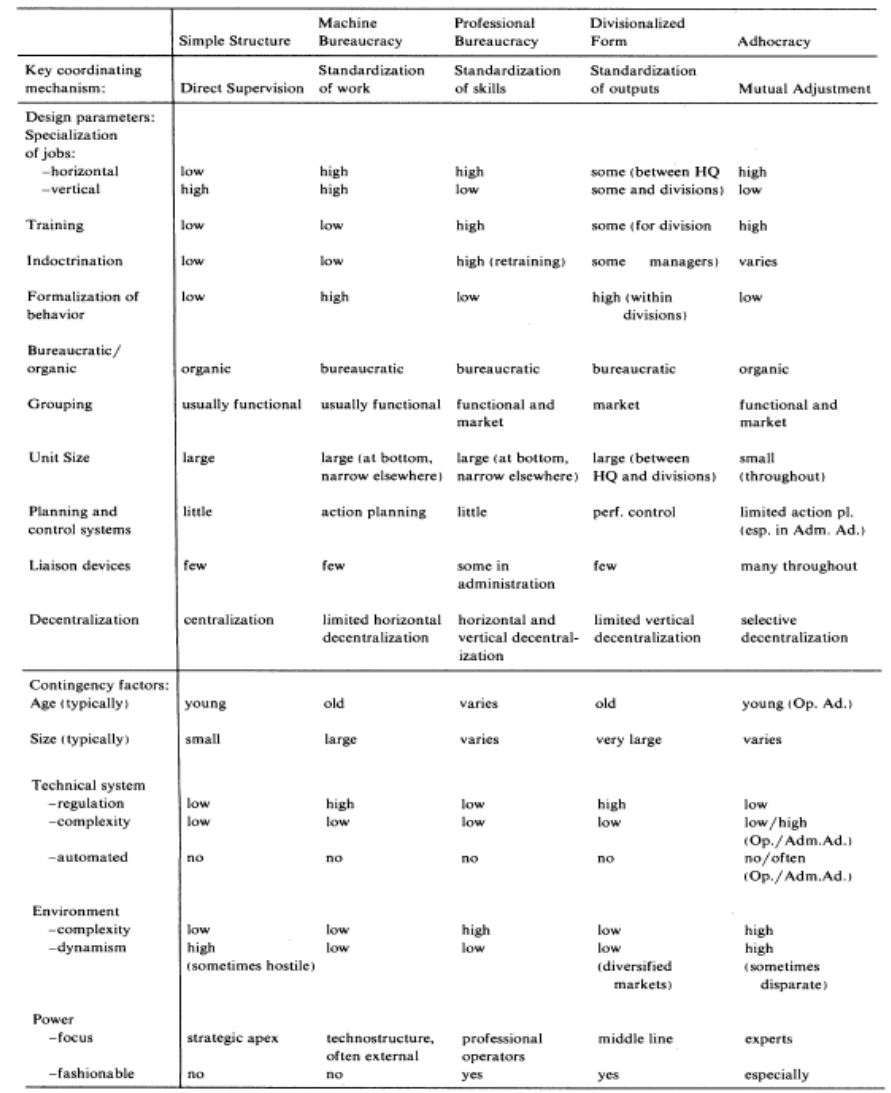

In government and business, asset management is performed in order to implement the principle of good governance that encompasses accountability, participation, and openness. Public asset management is an interrelated process and does not end. Thus, the public asset management process not only manages finances, but also manages resources, notes the problems that arise in the asset management process, provides solutions for problems solving, monitoring, and evaluation. The management of public assets in managing assets is not only done on one field of organization only, but also manage from many fields. (Woodhouse, 2006) 
Royal Institution of Chartered Surveyors shortened RICS gave a guideline to implement effective asset management. (Jones and White, 2008). The advantage of RICS model is that it offers a simpler model so that it is majorly used by various countries in managing their public's asset. The various activities can be explained in managing an asset in every part of its process. This illustrates that in managing asset, we cannot rely on only one division in the organization but also coordinate with all of the divisions in it. The RICS has been applied in several countries such as Australia, England dan the United States of America with a high level of success. (Jones and White, 2008)

\section{RESEARCH METHODS}

The method that was used by the researcher is a qualitative method. The method was chosen to obtain comprehensive understanding. In collecting data, the researcher used comprehensive interviews and also literature study. Comprehensive interviews act as the technique to obtain primary data, while literature study was used to obtain secondary data. The researcher used qualitative data collection in order to obtain information that is comprehensive about the research topic. The informants are the Director of the State Asset Management Agency to find out the overall information of LMAN's organizational structure and asset management process that LMAN will undertake, the Head Chief of the Organization and Internal Secretariat Obedience DJKN to find out the process of establishing LMAN, the Head of Division IB Secretariat Ministry of Finance to find out the process of establishing LMAN. Secondary data was obtained from books, journals, documents, the Internet, and things that are related to the discussion. The literature study was used to collect information on the history of asset management in Indonesia, the various policies underlying asset management in Indonesia, and the report of the relevant agencies on asset management in Indonesia. Data collection was conducted from April to June 2017.

Strategy for data analysis used is Ideal Type. Through the ideal method of type, Neuman (2007) argues that researchers apply the theory as a thing that is considered ideal. Existing theory is compared to facts on the ground. These facts will determine whether the conditions on the ground are ideal if based on the theory raised. Ideal Type Usage is not intended to prove a theory, but this strategy researchers use to put theory as a tool of researchers in the process of analysis in order to translate empirical data.

\section{RESULTS}

\section{A. Challenges that are faced by LMAN}

As an institution that functions as the operator of State's asset management, LMAN is an answer to the problems and challenges about asset management in Indonesia. However, many challenges is faced LMAN because the status of public service agency (Indonesian: Badan Layanan Umum, shortened BLU). First, BLU's financial management pattern is different from other work units. LMAN itself gets BLU status with special treatment. Other BLUs usually get the status after about two years of operation with some terms and conditions, whereas LMAN got its status since its establishment. It means that LMAN must be able to independently perform financial management since its establishment. Of course, this responsibility is greater when compared with that of an ordinary non-BLU work unit, "So BLU is like a stamp; the stamp of financial management by public service agency, which affects the flexibility. Once it has a profit, the money can be used for office operations, buy more buildings, or anything at all." (Interview with the Head Chief of the Organization and Internal Secretariat Obedience DJKN, on May 3, 2017). LMAN's flexibility does seem to simplify LMAN's work, but in fact, it is very risky, "But if you talk about risk, it's all the same. LMAN is at an even greater risk if we're seeing things from the administrative side of the country because if a negotiation comes off really easily, it means more risk and responsibility. Because the previous one had a rule, say I want to have an appointment outside of the office, I'm not allowed. Same goes to while having a lunch. If this is allowed, there'll be more opportunity for gratification, but it's actually possible for them to do such things, the rules make it so" (Interview with the Head Chief of the Organization and Internal Secretariat Obedience DJKN, on May 3, 2017).

The second is related to the organizational structure. From the very beginning in Indonesia, there was no institution doing the job. All previous land financing projects were undertaken by the relevant independent agencies. "Last March 2016 we got a new mandate to do all land funding for every central government project, this also proved a challenge for us. Because we were the first government agency to do this. Previously the land financing was done by the respective agencies." (Interview with the Director of the State Asset Management Agency, on May 24, 2017).

Imbalance in the division of functions at division and subdivision levels poses challenges in the form of divisions that carry more functions will consequently have more jobs and responsibilities. The same thing happens at the subdivision level, the subdivisions that have more functions will have more jobs and responsibilities. Different workloads that occur is a challenge that LMAN must complete, and it ranges from the composition of human resources in each division, performance allowances, and so forth. The addition of the new mandate as a special land bank will add to LMAN's challenge if it continues to be run with the current organizational structure formation.

The third challenge is related to LMAN status as a nonechelon institution. The status of LMAN as a new institution that has only been running for about half a year is a challenge that must be solved. Unstable organizational conditions are one of the challenges due to the organization's newly established nature. Many important positions are still empty, so many LMAN officials concurrently occupy positions to fill vacant positions. "Vacancy is an inside challenge that we are currently facing, there are still a lot of unoccupied positions, so many [officials] are doing double duty to fill vacant positions, and we also ask for help from the private sector to fill those." (Interview with the Director of the State Asset Management Agency, on May 24, 2017). 
The limited human resources to fill positions is the fourth challenge. LMAN is currently doing an open recruitment to fill vacant positions, "last month we did a massive recruitment, if you checked the Ministry of Finance's website last month, you would've noticed the announcement that LMAN was doing recruitment, the announcement was very visible and very clear." (Interview with the Director of the State Asset Management Agency, on May 24, 2017). The recruitment of human resources has also sparked a new challenge. LMAN is a very technical institution and has a heavy workload, and it is in need of experts in different fields. LMAN should not recruit any people who do not possess enough experience in the field of asset management, "the recruitment we did last time was still within the Ministry of Finance and DJKN. As of now we still aren't open to just any candidates, because it's a necessity to recruit just the experts in the management of assets or state assets, so it's not quite possible for us to open out, let alone to recruit fresh graduates." (Interview with the Director of the State Asset Management Agency, on May 24, 2017).

The next challenge is related with the huge responsibility burdened to LMAN itself including the LMAN's duties stated in the Regulation of the Minister of Finance number 219 on the Organization and Working Procedures of the LMAN, which is to increase Non-Tax State Revenue (PNBP). This PNBP is generated from potential assets in Indonesia. This potential asset is what will be managed by LMAN to be optimal. The optimization of asset management is done by leasing unused potential assets to the required parties, selling or transferring status. In addition, LMAN's status as a unit of Public Service Agency (BLU work unit) is also a separate problem. The status as BLU work unit, on one hand, does make LMAN's movement more flexible, but it is a challenge for LMAN to be able to manage financial management independently. LMAN's age that has not yet reached two years is too early if it has to deal with the challenge as a BLU work unit. LMAN must also solve the problem of double inefficiency that has been happening in Indonesia. It is called double inefficiency because there have been many potentials but ultimately wasted assets. This means that the country has been experiencing opportunity loss in terms of assets that otherwise could have been beneficial, but not utilized. On the other hand, the government always experienced a deficit state budget posture, one of the reasons this deficit happens is that during the planning of an infrastructure development project, the budget used was from capital expenditure in APBN. One of the purposes of LMAN is to solve this problem. The capital expenditure budget in APBN is expected to be transferred into investment budget in APBN so that the state budget posture can slightly improve.

The last challenge is the overly lean organizational structure. At the division level, the two divisions that exist based on the division of functions are very feeble. Of the seven existing LMAN functions, the operational division is assigned to carry out six functions, while the financial and organizational support divisions run only one function. Not much different when viewed at the subdivision level. Under the operational division, there are four subdivisions. Division of functions to the four divisions are also unequal. The organizational structure posture of LMAN increasingly looks too slim if considering that the new mandate for LMAN is given in terms of the special function of a land bank. Functions that have never previously existed in any institution in Indonesia will be a very difficult challenge for LMAN, especially if relying solely on the current organizational structure.

\section{B. The Ideal Organizational Structure for LMAN}

The challenges LMAN faces largely have three main functions: property management or asset management, advisory, and financing and land acquisition. "In general, there are three reasons for this: one, operates the operator of BUN asset optimization, two, land financing, and three, as an advisory." (Interview with the Director of the State Asset Management Agency, on May 24, 2017). These three functions will serve as the main framework for analyzing the existing LMAN organizational structure.

In addition, LMAN's coordination mechanism to date is a coordination mechanism based on the standardization of output, "well truth to be told, the coordination of the director is about the commitment of the director, and then later on we can see from the functional organization that LMAN's concern relies on the output." (Interview with the Director of the State Asset Management Agency, on May 24, 2017). Coordination mechanisms that prioritize output standardization are often used in a variety of private corporations that are very concerned about prioritizing outcomes above others.

Looking at Mintzberg's theory, an organization whose coordination mechanism prioritizes the results or outputs should be structured in the form of The Divisionalized Form. The Divisionalized Form has several criteria of marketoriented, average age because of the need for more experienced people, the big responsibility, applying perfect control in carrying out tasks and functions, as well as parts that have dominance in the organizational structure, exist at the middle line level. This market orientation has been carried out by LMAN by forming a work unit organization that obtains financial management pattern of Public Service Board. This BLU work unit is what makes LMAN a government institution, but it is like a private organization. "LMAN's pattern is different because it uses BLU financial pattern, where there must be profit oriented where the goal is to increase PNBP, there are no other options but to use a new way." (Interview with the Director of the State Asset Management Agency, on May 24, 2017)

Furthermore, the average age that tends to be older also appears visibly from the age composition of LMAN employees. LMAN has an average age that is of "experienced" age, "from the current range, probably the youngest ones are the $90 \mathrm{~s}$ born, the oldest are $60 \mathrm{~s}$ but the average is 80 s born." (Interview with the Director of the State Asset Management Agency, on May 24, 2017). Job vacancies were already held by LMAN, no vacancies opened for fresh graduates or individuals with no experience of working in asset management. 
The great responsibilities mentioned in the previous discussion also further reinforce the view that LMAN is well suited to the configuration of The Divisionalized Form. In Mintzberg's theory, The Divisionalized Form is the configuration that has the greatest responsibility compared with other configurations. It is perhaps the most important factor of the role of some division heads that is the main dominance of this configuration.

Such a big responsibility makes LMAN require a strict supervisory system. At LMAN itself, a meeting to discuss the progress and plans that will be implemented during the next week is held every Monday, "because indeed every time we will discuss with the project owner we also have Monday Meeting every Monday. We have a meeting to plan what future outcomes and direction we are doing there." (Interview with the Director of the State Asset Management Agency, on May 24, 2017)). It is also in accordance with the configuration of The Divisionalized Form on Mintzberg's theory that must apply perfect control in conducting supervision and planning in every activity.

The next criterion that must be possessed is the dominance of the structure by the middle line. The Middle Line in Mintzberg's theory can be interpreted as the division head that connects the highest level of the director to the bottom level, in this case, the executor or staff. This is what LMAN lacks. The Middle Line that is supposed to have a dominant role in such a structural configuration cannot be filled by only one person, the head of the operational division with some of the major functions mentioned earlier. If LMAN wants to be results-oriented to increase its benefits, then the Divisionalized Form configuration is the most suitable to apply because the main coordinating mechanism in the Divisionalized Form is the standardization of output, so the performance of managers and organizations is judged on the basis of their output. To make the structure with that configuration at least LMAN must divide divisions based on their main functions.

Divisions can be divided into three divisions that focus on the operationalization of existing activities. These three divisions are in line with the three main functions of LMAN. It would be better if LMAN breaks its existing operational divisions into three divisions based on the main functions of the property management division, asset management consulting division or advisory, and the land supply and financing division. The division can be said to be sufficient to give LMAN the configuration of the Divisionalized Form in which the dominance of The Middle Line is visible with every major function headed by one division head.

\section{CONCLUSION}

The challenges LMAN is facing require it to clean up to be optimum in carrying out its duties and functions. A new design is needed to resolve the challenge. The organizational structure created must really consider from some tasks and functions that are getting heavier every year. Inequality between divisions and subdivisions is expected to be solved by the design of a new organizational structure. Further studies are required to see LMAN's proper redesign strategy to improve on the issues discussed.

\section{References}

[1] Antaranews. (2017, Januari 17). Antaranews. Diakses melalui Antaranews.com: http://www/antaranews.com/berita/104722/ma-mintamantan-hakim-agung-tinggalkan-rumah-dinas.

[2] Jones, K and White, A.D., (ed.). (2008). RICS Public Sector Asset Management Guidelines, United Kingdom: Royal Institute of Chartered Surveyors.

[3] Kantor Pelayanan Kekayaan Negara dan Lelang. (2014). Ikhtisar BMN Tidak Terpakai. Jakarta: Direktorat Jenderal Kekayaan Negara.

[4] Kompas. (2017, Januari 12). Cerita Saat Kompleks Istana Belum Tercatat sebagai Aset Negara. Diakses melalui kompas.com: http://bisniskeuangan.kompas.com/read/2016/11/02/221624826/cerita.sa at.kompleks.istana.belum.tercatat.sebagai.aset.negara.

[5] Law Number 1 Year 2004 on State's Treasury.

[6] Mintzberg, H. (1980). The Structure in 5's: A Synthesis of The Research on Organization Design. Management Science, 26 (3), 322-341

[7] Netralnews. (2017, Januari 12). Karena Jual Tanah Negara, Direktur PT Adhi Karya Diperiksa Kejagung. Diakses melalui Netralnews.com: http://www.netralnews.com/news/hukum/read/29470/karena.jual.tanah.n egara..direktur.pt.adhi.karya.diperiksa.kejagung

[8] Neuman, W. L. (2007). Social Research Methods Qualitative and Quantitative Approaches. Boston: Allyn and Bacon

[9] The Ministry of Finance. (2015). Central Government Financial Report. Jakarta: The Ministry of State Secretariat.

[10] Woodhouse, John. (2006). Asset Management. The Woodhouse Partnership Ltd. 